\title{
Saproxylic beetles of conservation interest in the Calabrian side of the Pollino National Park (Calabria, Italia): Lucanus tetraodon Thunberg, 1806, Osmoderma italicum Sparacio, 2000, Cerambyx cerdo Linnaeus, 1758 and Rosalia alpina (Linnaeus, 1758) (Coleoptera Lucanidae Cetoniidae Cerambycidae)
}

Sandro Piazzini', Matteo Tamburini', Francesco Rotondaro², Vittoria Marchianò ${ }^{2}$, Francesca Martini ${ }^{3} \&$ Leonardo Favilli'

${ }^{1}$ Department of Physical Sciences, Earth and Environment, University of Siena, via P.A. Mattioli 4, 53100 Siena, Italy

${ }^{2}$ Entity of the Pollino National Park, Monumental Complex of Santa Maria della Consolazione, 85048 Rotonda, Potenza, Italy

${ }^{3}$ D.R.E.AM Italia, Via Garibaldi, 3 -52015 Pratovecchio Stia, Arezzo, Italy

Corresponding author, e-mail: piazzini5@unisi.it

ABSTRACT In this article an update on the distribution of Coleoptera Lucanus tetraodon Thunberg, 1806 (Lucanidae), Osmoderma italicum Sparacio, 2000 (Cetoniidae), Cerambyx cerdo Linnaeus, 1758 and Rosalia alpina (Linnaeus, 1758) (Cerambycidae) in the Calabrian side of the Pollino National Park is described. Data regarding the ecological part and the conservation status will be presented for each species. Therefore, of particular interest it can be noted: the presence in nine locations of L. tetraodon, an uncommon species and with little-known distribution; the discreet diffusion of $O$. italicum, rare and with a very restricted area, found in thirteen locations up to over $1800 \mathrm{~m}$ of altitude; C. cerdo for the Calabrian side of the National Park of Pollino; the first data for the presence of $R$. alpina at $1900 \mathrm{~m}$ altitude, the highest recorded in Italy and the discovery of larval stages on Italian alder (Alnus cordata), never ascertained in Italy. The Pollino National Park is confirmed as one of the areas of greatest national importance for the conservation of these xylophagous species linked to old forests.

KEY WORDS Coleoptera; Pollino National Park; Calabria; Italy; saproxylic beetles; distribution; ecology.

Received 30.08.2020; accepted 01.12.2020; published online 30.12.2020

\section{INTRODUCTION}

The Pollino National Park, established in 1993, is the largest protected area in Italy, with a coverage of 192.565 ha, divided between Calabria and Basilicata. The Calabrian side has an extension of 103.915 ha and includes three mountain groups, the Ciagola chain that extends toward west in the hy- drographic right of the Lao River, between Laino Borgo and Santa Domenica Talao, the Pollino in the central that marks the border between Basilicata and Calabria and the Orsomarso mountains that extend in the southwestern portion between the locality of the same name and Serra La Vriglia at Belvedere Marittimo. The maximum elevation is represented by the Serra Dolcedorme (2267 m), the 
highest peak of the Pollino. From a geological point of view, the substratum consists almost entirely of limestone soils belonging to three carbon units, that of Lungro-Verbicaro, that of Pollino-Ciagola and that of Cetraro (Iannace et al., 2005; 2007); near San Donato di Ninea there are also clay shale belonging to the San Donato unit (Ietto \& Ietto, 2011).

With regard to vegetation, the forest environments occupy $56 \%$ (about 58.000 ha) of the Calabrian side. The most spread typologies are the beech forests, that cover an area from 1300-1400 $\mathrm{m}$ up to almost $2000 \mathrm{~m}$; from $600-700 \mathrm{~m}$ up to $1300 \mathrm{~m}$, depending on the type of soil and exposure, mixed mesophilous broadleaf woods. The most common species are: manna ash Fraxinus ornus L. (1753); European hop-hornbeam, Ostrya carpinifolia Scop. (1772); Italian alder, Alnus cordata (Loisel.) Duby (1828); field maple, Acer campestre L. (1753); Italian maple Acer opalus Mill. (1768); sycamore Acer pseudoplatanus L. (1753), but also oaks: (especially Turkey oak, Quercus cerris L. (1753), downy oak, Quercus pubescens Willd. (1796) and holm oak woods Quercus ilex L. (1753); instead, the reforestation of conifers and riparian vegetation is not very extensive (Gargano et al., 2012; Valicenti \& De Vivo, 2015). These forests, as happened throughout Italy, have been widely exploited, but various old parts has remained, which represent a shelter for saproxilic insects, largely saved from cutting. This is probably due to their position, that was difficult to reach. In the case of oakwoods, they were also maintained for the use of the acorn, both for food and as forage for pigs.

Thanks to a study on the species of insects of community interest present in the Natura 2000 network sites (PO FESR 2014-2020), promoted by the Environment and Territory Department of the Calabria Region and by the Pollino National Park Authority, in the two-year period 2018-19, careful research was carried out on the presence and distribution of Cerambyx cerdo Linnaeus, 1758, Rosalia alpina (Linnaeus, 1758), Osmoderma italicum Sparacio 2000 and Lucanus tetraodon Thunberg, 1806 and on the Calabrian side of the Pollino National Park.

The aim of this contribution is to outline an updated picture on the distribution of these species in addition to providing news on ecology, considering that the data available for the southern areas of these species are very poor.

\section{MATERIAL AND METHODS}

\section{Samples}

The research was carried out between July 2018 and August 2019 in all the Calabrian side of the Pollino National Park (Fig. 1).

Cerambix cerdo has been sampled either through direct adult research and / or remains in suitable habitats near large and old oak trees. This was accomplished either with the use of falling-fall air traps, or by using mature fruit traps (Trizzino et al., 2013; Bologna et al. in Stoch \& Genovesi, 2016; Redolfi De Zan et al., 2017).

Rosalia alpina has been investigated through direct research into perishable and dead beech trees, living or with dead portions of them (Trizzino et al., 2013; Bologna et al. in Stoch \& Genovesi, 2016).

To estimate the size of populations, in three localities with at least five dead or perishable trees distributed over one area of one hectare (Pollino: Fagosa to Fosso del Vascello and Fagosa Plan; Orsomarso Mountains: Frida and Campicello), three visits were made within two weeks and during these visits, these insect populations were counted with photographic marking and recapture.

Osmoderma italicum has been investigated both through direct adult search on logs and / or cavities and remains, larva and cocoons in woody beads, or by using attractive interception traps (BCWT, black cross window trap) (Trizzino et al., 2013; Bologna et al. in Stoch \& Genovesi, 2016). The BWCT, set with the pheromone ( $\gamma$-decalactone), were placed in a minimum number of six, at least $50 \mathrm{~m}$ apart; the traps were checked in alternate days for at least one week.

Lucanus tetraodon has been sampled through direct adult and / or remains on logs and / or cavities; activities have always taken place in the afternoon, when the species is more active (Trizzino et al., 2013; Bologna et al. in Stoch \& Genovesi, 2016; Bardiani et al., 2017).

\section{Methods}

For each species a label divided into two paragraphs is reported: in the first (Exhibit), the examined materials, the number, the sex of the sampled species, the collection place, the geographical coordinates, the altitude, the municipality, the acronym of the province (in brackets) and the col- 


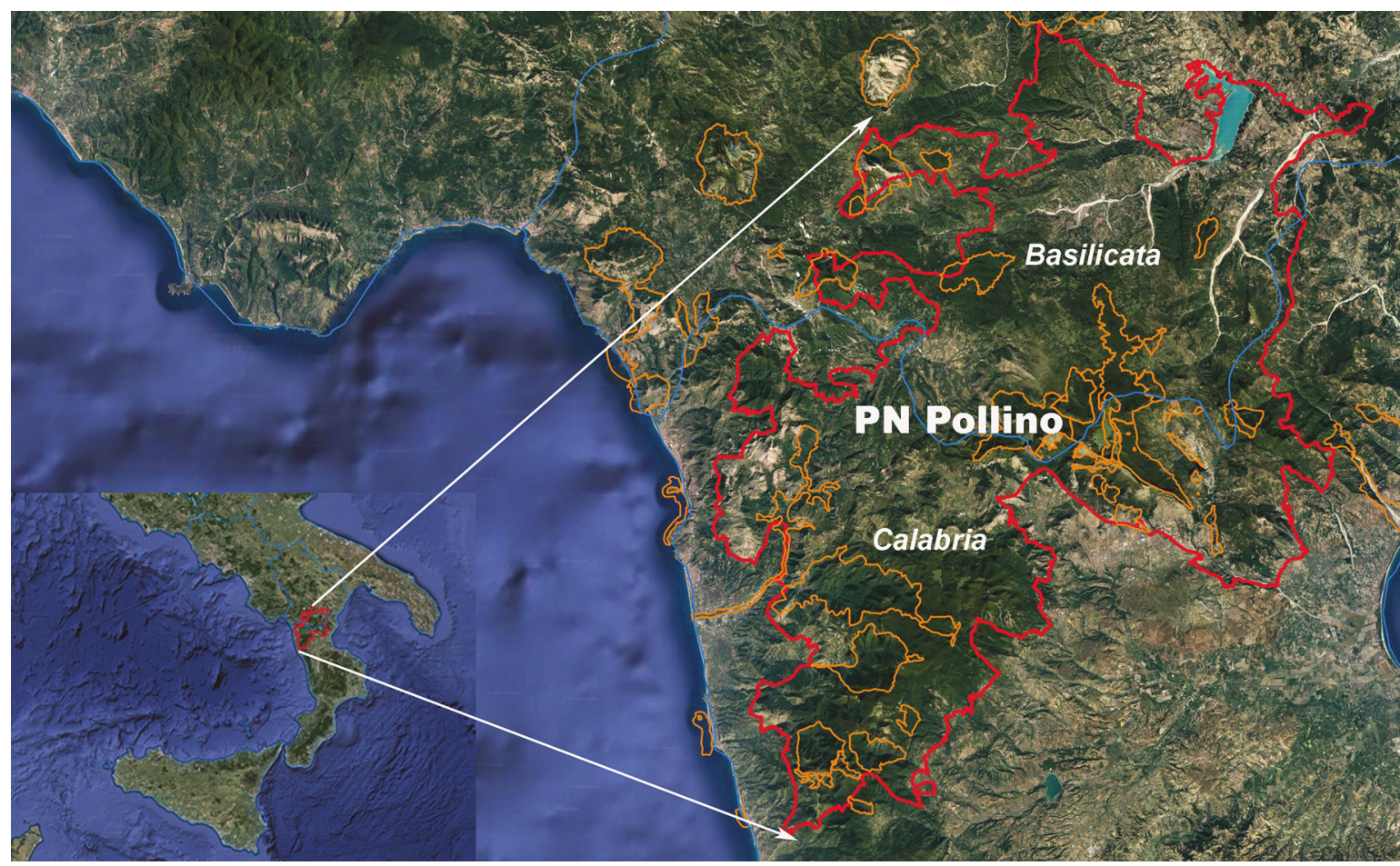

Fig. 1. Area of study. Red line is the limit of the PN Pollino; the blue line is the limit between regions; the orange lines delimit the Sites of Community Importance.

lector/s $(\mathrm{SP}=$ vidit/legit S. Piazzini; $\mathrm{MT}=$ vidit/legit M. Tamburini; SP \& MT= viderunt/legerunt S. Piazzini \& M. Tamburini; FR= vidit/legit F. Rotondaro; $\mathrm{VM}=$ vidit/legit $\mathrm{V}$. Marchianò; VM \& SP= viderunt/legerunt V. Marchianò \& S. Piazzini.) are listed; in the second (Observations), information on the distribution, biology, ecology and status of conservation of the examined species are provided and elaborated. Abbreviation ZSC $=\mathrm{SAC}$, Special Area of Conservation.

For reasons related to the conservation of the species, the precise location of the sites has not been indicated, omitting to indicate the latter in the geographical coordinates of the collection locations.

\section{RESULTS AND DISCUSSIONS}

\section{LUCANIDAE}

Lucanus tetraodon Thunberg, 1806 (Fig. 2)

EXAMINED MATERIAL. $1 \widehat{\delta}$ adult, Chain of Ciagola, Contrada Pedali, 3956’N 155'ㄹ, 650 m, Laino Borgo (CS), 8.08.19, MT; 1 đodult and 1 I adult, Chain of Ciagola, Gada Mountain, $39^{\circ} 56^{\prime} \mathrm{N} 15^{\circ} 54^{\prime} \mathrm{E}, 970 \mathrm{~m}$, Laino Borgo (CS), 31.07.19, SP; 1 त adult, Pollino, at Fonte Scosa, $39^{\circ} 49^{\prime} \mathrm{N} 16^{\circ} 20^{\prime} \mathrm{E}, 700 \mathrm{~m}$, Francavilla Marittima (CS), 26.07.19, SP; 1 ô adult and 1 q adult, Pollino, at S. Maria delle Armi, 3950'N 16² $21^{\prime} \mathrm{E}$, 1050 m, Cerchiara di Calabria (CS), 26.07.19 e 10.08.19, SP; 1 adult, Mountains of Orsomarso, Carpinosa, 3945'N 1559'E, 750 m, San Donato di Ninea (CS), 12.08.19, SP; 1 đo adult, Mountains of Orsomarso, Casiglia, 3941'N 1600'E, 985 m, San Sosti (CS), 25.07.19, SP; 1 ते adult and 1 ㅇ adult, Mountains of Orsomarso, near Piano di Marco, 394 ' 'N 1600'E, 1035 m, San Donato di Ninea (CS), 25.07.19, SP; $2 \delta^{\lambda}$ adults and 2 우

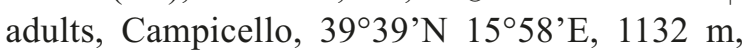
Mottafollone (CS), 28.07.19 e 11.08.19, SP; 1 ઈ adult, Mountains of Orsomarso, Monte Spina Santa, 39³9'N 1558'E, 1138 m, Sant'Agata di Esaro (CS), 28.07.19, SP.

OBSERVATIONS. Species present in north-eastern Spain, in Provence (France), in Corsica and in a large part of Italy, from the Ticino valley (Piedmont 


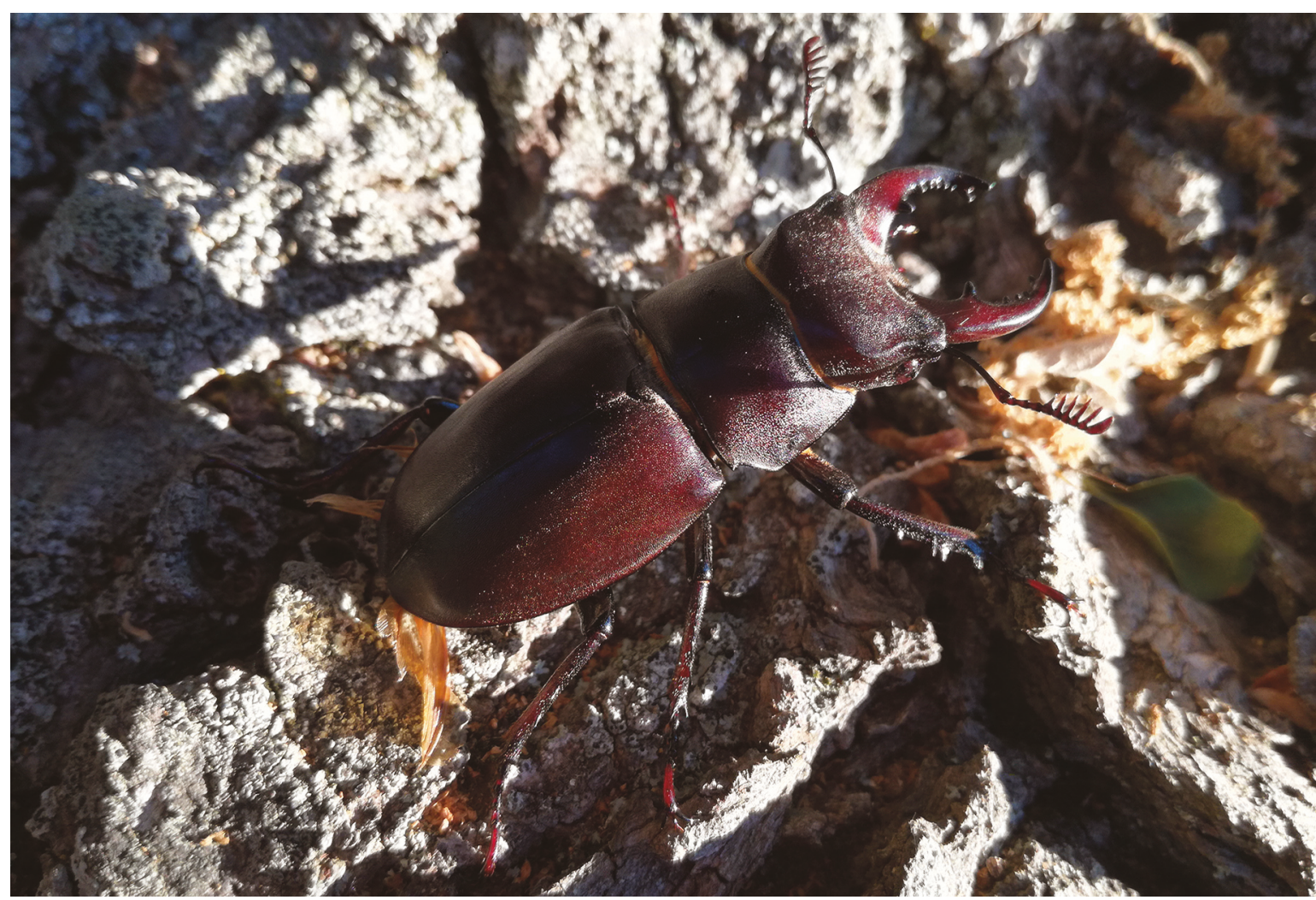

Figure 2. Lucanus tetraodon near Fonte Scosa, Pollino (photo S. Piazzini).

and Lombardy) to the south up to include Sicily, Sardinia and Elba; there are some vague and dated reports for Algeria and the Balkans (Albania) which however need confirmation. L. tetraodon is a saproxylophagous beetle, linked to thermophilic and mesophilous broadleaf woods, generally of cork oak Quercus suber L. (1753), holm oak and other species of oaks, but also of other Fagaceae, from sea level up to $1300 \mathrm{~m}$ of altitude. The larva develops, up to 3-4 years, in dead wood in the stumps of old plants. The period of greatest adult activity is probably between June and August, mainly in the afternoon and evening (Sforzi \& Bartolozzi, 2001; Zilioli \& Pittino, 2004; Beltrán \& Beltrán, 2009; Nieto et al., 2010; Bardiani et al., 2017; Sindaco et al., 2019).

Although it is a sub-endemic Italian species and generally less common than the stag beetle, $\mathrm{Lu}$ canus cervus Linnaeus, 1758, it is poorly known in terms of distribution in southern Italy (known for only 11 locations in Calabria; Ruffo \& Stoch, 2007). Concerning ecology, it is not unfortunately mentioned in any of the main fauna protection reg- ulations (in contrast to L. cervus included in Annex II of Directive 92/43 / EEC and in Annex III of the Bern Convention) despite the undeniable interest from the zoogeographic point of view.

L. tetraodon, known so far for the Calabrian side of the Pollino Park only for three dated detections (Valico di Campotenese, Convent of Colloreto and Monte Pollino) (Ruffo \& Stoch, 2007), was found in nine unpublished locations, three of which fall in as many ZSC (Carpinosa: IT9310028 Valley of the Abatemarco River; Piano di Marco in the homonymous ZSC IT9310022; Campicello: IT9310027 Rosa River). The sites are between $600 \mathrm{~m}$ and 1140 $\mathrm{m}$ and are all characterized by the presence of woods with a prevalence of Fagacee (holm oak, downy oak, turkey oak, beech) with the presence of old plants, in some cases even old, generally large and with stumps or other portions dead or perishing.

The host plants of the larva are represented in three cases by the turkey oak, in two cases by the downy oak, in one case by the holm oak and in three cases by the beech; at lower altitudes the species 
also lives inside the wood, while going up in altitude it seems to prefer much more open situations, with the host plants placed in full sun.

Of particular interest are the cases of Campicello and Monte Spina Santa, where the host plant is represented by beech instead of oak species; in these two locations L. tetraodon lives within a short distance of $R$. alpina but the two species compete on a trophic level; in fact in the microhabitat (i.e., the dead plant) the two species are mutually exclusive and L. tetraodon is found in the broadest and sunniest cuttings. Rosalia alpina, instead, is found on dead plants in smaller, less sunny cuttings or at the edge of the forest. In three locations (Piano di Marco, Spina Santa Mountain, Gada Mountain), this species lives in the same microhabitat with $O$. italicum and in two locations (at Fonte Scosa, near S.Maria delle Armi) with $O$. italicum, M. asper, $C$. cerdo and Cerambyx welensii (Küster, 1846); in these cases the presence of one xylophagous species does not exclude the other, probably because each one uses a different part of the dead plant ( $L$. tetraodon the stump, O. italicum the mould in the cavities, $M$. asper the dead branches fallen on the ground and the Cerambyx the dead parts still standing).

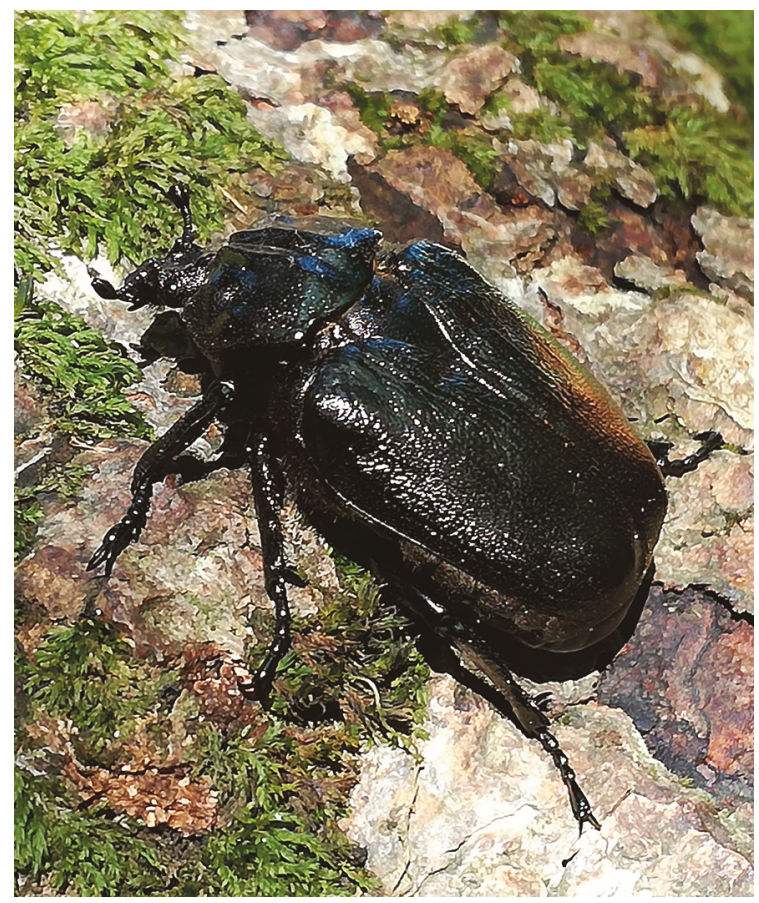

Figure 3. Osmoderma italicum near Timpone Vaccaro, Mountains of Orsomarso (photo S. Piazzini).
In the area under investigation, the main threats are removal of dead trees and fires.

\section{CETONIIDAE}

\section{Osmoderma italicum Sparacio, 2000 (Fig. 3)}

EXAMINED MATERIAL. 1 adult, Chain of Ciagola, Gada Mountain, 3956’ N 15 ${ }^{\circ} 54^{\prime} \mathrm{E}, 1030$ $\mathrm{m}$, Laino Borgo (CS), 31.07.19, SP; 1 స̂ adult, Pollino, Sparviere Mountain, 39 $55^{\prime} \mathrm{N} 16^{\circ} 21^{\prime} \mathrm{E}$., $1300 \mathrm{~m}$, Alessandria del Carretto (CS), 1416.08.18, SP; 1 q adult, Pollino, Piano di Acquafredda, $39^{\circ} 54^{\prime} \mathrm{N} 16^{\circ} 13 \mathrm{E}, 1860 \mathrm{~m}$, Cerchiara di Calabria (CS), 8.08.18, VM; 1 q adult, Pollino, near Colle Marcione, 3952’ N 16²17'E, $1261 \mathrm{~m}$, Frascineto (CS), 21.07.19, FR; 1 q adult, Pollino, near Fonte Scosa, 3949’N 16²0'E, 700 m, Francavilla Marittima (CS), 22.07.19, SP \& MT; 1 ㅇ adult, Pollino, Cernostasi, 3950’N 16²19'E, 785 m, Francavilla Marittima (CS), 18.07.19, SP \& MT; 1 \& adult, Pollino, near S. Maria delle Armi, $39^{\circ} 50^{\prime} \mathrm{N} 16^{\circ} 21^{\prime} \mathrm{E}, 1050 \mathrm{~m}$, Cerchiara di Calabria (CS), 26.07.19 e 10.08.19, SP; complete remains of $1 \bigcirc$ adult, Mountains of Orsomarso, side N di Serra della Lupara, $39^{\circ} 48^{\prime} \mathrm{N} 16^{\circ} 04^{\prime} \mathrm{E}, 1680 \mathrm{~m}$, Saracena

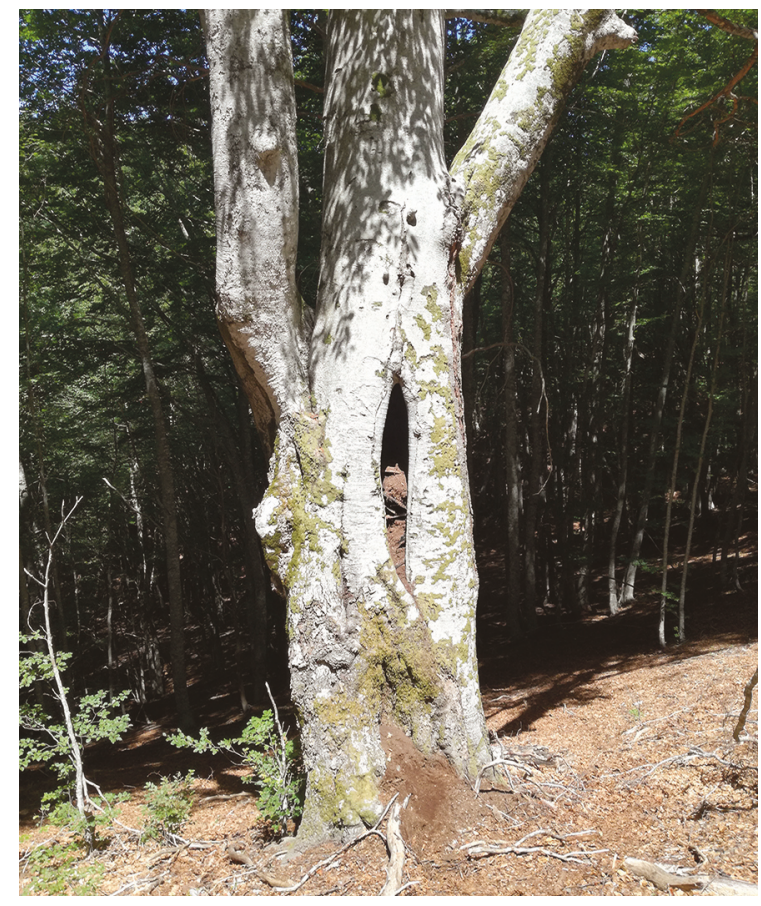

Figure 4. Habitat of $O$. italicum near M. Petricelle (photo S. Piazzini). 


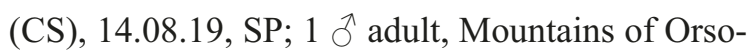
marso, side E di Timpone Vaccaro, 3949'N $16^{\circ} 02^{\prime} \mathrm{E}, 1255 \mathrm{~m}$, Saracena (CS), 22.08.18, SP; 1 $q$ adult, Mountains of Orsomarso, San Donato di Ninea, 39 $43 \mathrm{~N} 16^{\circ} 02^{\prime} \mathrm{E}, 1091 \mathrm{~m}$, San Donato di Ninea (CS), SP \& MT; 1 adult, Mountains of Orsomarso, at Piano di Marco, 39 $41^{\prime} \mathrm{N} 16^{\circ} 00^{\prime} \mathrm{E}$, 1006 m, San Donato di Ninea (CS), 25.07.19, SP; complete remains di $1 \widehat{\delta}$ adult, Mountains of Orsomarso, Spina Santa Mountain, 39³9’N 1558'E, 1138 m, Sant'Agata di Esaro (CS), 28.07.19, SP; complete remains di 19 adult, Mountains of Orsomarso, side $\mathrm{N}$ di Monte Petricelle, 39³9'N 1554'E, 1462 m, Buonvicino (CS), 7.08.19, SP \& MT.

OBSERVATIONS. Endemic species of southern Italy, currently known for few places in Campania, Puglia, Basilicata and Calabria. Some authors, following molecular investigations, have confirmed the affinity of $O$. italicum with $O$. eremita (the latter spread in western Europe) and consider $O$. italicum a taxon on the border between an allopatric species and a semi-species in the process of being differentiated (Audisio et al., 2007; 2009). O. italicum is a saproxylophagous beetle, tied to broad-leaf woods with the presence of large rotting trees characterized by medium and large cavities with degraded necro mass inside in the form of woody mould (which feeds the larva), where it lays its eggs. From the available data, $O$. italicum, which is found mainly from high hills (600 m) up to $1600 \mathrm{~m}$, seems more tied to woods and forests than the congeneric $O$. eremita who is found, however, very often, in agroecosystems with the presence of rows or sporadic willow plants. The period of greatest activity of adults is probably between June and August (Trizzino et al., 2013; Mazzei et al., 2014; Bologna et al. in Stoch \& Genovesi, 2016; Mazzei \& Brandmayr, 2017). The species is mentioned in Annexes II and IV of Directive 92/43 / EEC and is considered "In danger" in Italy and "Near Threatened" globally (Nieto et al., 2010 in IUCN, 2020; Rondinini et al., 2013 in IUCN Italian Committee, 2020).

Osmoderma italicum, known so far in fourteen locations across the entire range of which only three falling on the Calabrian side of the Pollino Park, namely Morano Calabro, Alessandria del Carretto and La Mula Mountain (Ruffo \& Stoch, 2007; Mazzei et al., 2014; Mazzei \& Brandmayr, 2017), was found in thirteen locations, eleven of which new: six locations fall within the ZSC (IT9310019 Monte Sparviere; IT9310014 Fagosa-Timpa dell'Orso; IT9310022 Piano di Marco; IT9310027 Rosa River; IT9310032 Serrapodolo). The detected places, located between $700 \mathrm{~m}$ and $1800 \mathrm{~m}$, are all characterized by the presence of deciduous forest (beech, downy oak, turkey oak, chestnut, Italian alder) with the presence of large, old trees, with large portions and cavities in the trunk (also located at the base) or in the branches, containing mould of partially decomposed wood (Fig. 4), confirming the greater forestry attitudes of $O$. italicum compared to $O$. eremita. The host plants of the larva are represented in seven cases by beech, in three cases by downy oak and in one case each by turkey oak, chestnut and Italian alder.

From the available data it seems that the flicker occurs from the second half of July, in the places with lower altitudes, and until the middle of August, in the higher places.

O. italicum lives with other xylophagous insects: in five cases with $R$. alpina, in two cases with L. tetraodon and in one case with $C$. cerdo and $M$. asper.

In relation to the territory under investigation, the main pressures / threats are represented by the cutting of dead trees, by the excessive human disturbance for outdoor activities and by the collection of insects.

\section{CERAMBICYDAE}

\section{Cerambyx cerdo Linnaeus, 1758}

Examined material. Complete remains of 2 adults $\widehat{\delta}$ and 1 adult $q$, Pollino, near S. Maria delle Armi, 39 $50^{\circ} \mathrm{N} 16^{\circ} 21^{\prime} \mathrm{E}, 1050 \mathrm{~m}$, Cerchiara di Calabria (CS), 26.07.19 e 10.08.19, SP \& MT; Complete remains 1 ते adult, Mountains of Orsomarso, near Piano di Marco, 39 $41^{\prime} \mathrm{N} 16^{\circ} 00^{\prime} \mathrm{E}, 1035 \mathrm{~m}$, San Donato di Ninea (CS), 25.07.19, SP.

OBSERVATIONS. Species widespread throughout central and southern Europe, from Spain to the east to Ukraine, in northern Africa, the Caucasus and Minor Asia. In Italy it is detected in all regions except Val d'Aosta. C. cerdo is linked to forests with a prevalence of oaks with the presence of large trees that are still viable but with perishing parts; can also be found more rarely on chestnut, willow, elm, wal- 
nut and ash. It lives from sea level up to $2000 \mathrm{~m}$ of altitude on the Atlas but in Italy it seems not to exceed $1300 \mathrm{~m}$. The larva develops in large oak trunks (at least $60 \mathrm{~cm}$ in diameter) by digging long tunnels and feeding on wood; reaches maturity at three to five years, when it metamorphoses. The period of major activity in the adults is between May and August (Buse et al., 2016 in IUCN, 2019; Stoch \& Genovesi, 2016; Redolfi De Zan et al., 2017). The species is listed in the attachments II and IV of Directive 92/43/CEE and it is considered as "Least Concern" at Italian and global levels (Rondinini et al., 2013 in IUCN Comitato Italiano, 2020; Buse et al., 2016 in IUCN, 2020).

Cerambix cerdo, for the time being, is not being alerted in the Calabrian side of Pollino Park, as it has been detected in two places, one in the ZSC IT9310022 Piano di Marco. The detection places are both located just over than $1000 \mathrm{~m}$ above sea level and characterized by the presence of forest with a prevalence of oaks (downy oak at S. Maria delle Armi and Turkey oak at Piano di Marco) with the presence of old, large plants, still viable but with some perishing parts. In both places $C$. cerdo lives with Morimus asper (Sulzer, 1776), O. italicum e L. tetraodon.

Extensive research should include sampling of the repeated species for several years, the low presence of this longhorn beetle in the area of survey is likely to be attributed to both the relatively limited extent of oak forests and to the low presence of large-size old oak trees, the primary habitat of the species.

In relation to the investigated territory, the main pressure is currently being represented by possible fires, given that the underlying hilly areas are often affected by the fire, and with regard to S. Maria delle Armi, the last one happened in July 2019, arriving almost in lapping such a place. Other threats appear to be the removal of dead and perishing trees and large ones derived by intensified agriculture, but also from the collection of specimens for collection purposes.

\section{Rosalia alpina (Linnaeus, 1758) (Fig. 5)}

EXAMINED MATERIAL. $1 \delta$ adult and $1 q$ adult, Chain of Ciagola, Gada Mountain, 3956'N 1554' E, 1030 m, Laino Borgo (CS), 31.07.19, SP; 1 ๙ adult and $1 q$ adult, Pollino, Sparviere Mountain, $39^{\circ} 54 \mathrm{~N} 16^{\circ} 21^{\prime} \mathrm{E}, 1287 \mathrm{~m}$, Cerchiara di Calabria (CS), 5.08.19, MT; $2 \pi$ adult and $2+$ adults, Pollino, La Fagosa near Fonte del Vascello, $39^{\circ} 53^{\prime} \mathrm{N} 16^{\circ} 14^{\prime} \mathrm{E}, 1410 \mathrm{~m}$, Castrovillari (CS), 27.07.18, 8.08.18 e 13.08.18, SP \& MT; 2 od adults and $4+q$ adults, Pollino, Piano della Fagosa, $39^{\circ} 55 \mathrm{~N}$ $16^{\circ} 13^{\prime}$ E, $1513 \mathrm{~m}$, Cerchiara di Calabria (CS), 8.08.18, 24.08.18 e 6.09.18, MV \& SP; 1 oे adult, Pollino, La Montagnola, 39 $55 \mathrm{~N} 16^{\circ} 13^{\prime} \mathrm{E}, 1650 \mathrm{~m}$, Cerchiara di Calabria (CS), 6.09.18, MV \& SP; 2 $\widehat{\gamma}$ adults and 2 adults, Pollino, Piano di Badia, $39^{\circ} 53^{\prime} \mathrm{N} 16^{\circ} 14^{\prime} \mathrm{E}, 1325 \mathrm{~m}$, Castrovillari (CS),

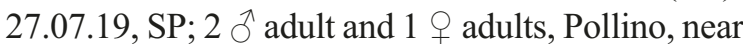
Colle Sparto, 39 $53^{\prime} \mathrm{N} 16^{\circ} 15^{\prime}$ E, 1200 m, San Lorenzo Bellizzi (CS), 27.07.19, SP; 1 † adult, Pollino, Piano di Ratto, 3952'N 1616' E, 1400 m, Frascineto (CS), 21.07.19 FR, 10.08.19 SP \& MT; 1 o adult, Pollino, Colle Ratto, 39 52’N 16²16' E, 1384 m, Frascineto (CS), 10.08.19, SP \& MT; 1 ते adult and $1 q$ adult, Pollino, northern side of Timpa del Principe, $39^{\circ} 52^{\prime} \mathrm{N} 16^{\circ} 15^{\prime} \mathrm{E}, 1457 \mathrm{~m}$, Frascineto (CS), 10.08.19, SP \& MT; $1 \delta^{\top}$ adult and 19 adults, Pollino, Pietra Caduta, 3952’ N 16 ${ }^{\circ} 15^{\prime} \mathrm{E}, 1521 \mathrm{~m}$, Frascineto (CS), 10.08.19, SP \& MT; 1 đ adult, Pollino, Costa di Malaverna, 3952’ N 16²15'E, 1754 m, Frascineto (CS), 10.08.19, SP \& MT; 1 え adult, Pollino, southern side of Serra Dolcedorme, $39^{\circ} 53^{\prime} \mathrm{N} 16^{\circ} 13^{\prime} \mathrm{E}, 1850 \mathrm{~m}$, Castrovillari (CS), 13.08.19, SP; 1 q adult, Pollino, southern side of Serra del Prete, $39^{\circ} 54^{\prime} \mathrm{N} 16^{\circ} 09^{\prime}$ E, 1540 m, Morano Calabro (CS), 26.08.18, VM \& SP; 1 đo adult and 1 q adult, Pollino, eastern side of Serra del Prete, $39^{\circ} 54^{\prime} \mathrm{N} 16^{\circ} 10^{\prime} \mathrm{E}, 1790 \mathrm{~m}$, Morano Calabro (CS), 26.08.18, SP; 1 đ̄ adult, Mountains of Orsomarso, northern side of Monte Palanuda, 3949'N 1600'E, 1535 m, Mormanno (CS), 25.08.18, SP; 1 q adult, Mountains of Orsomarso, northern side of Serra della Lupara, 3948'N 1604'E, 1680 m, Saracena (CS), 14.08.19, SP; 1 ऽ adult \& 2 adults, Mountains of Orsomarso, southern side of Monte Caramolo, 3947' N $16^{\circ} 05^{\prime} \mathrm{E}, 1690 \mathrm{~m}$, Saracena (CS), 14.08.19, SP; 1 đodult and $2 \bigcirc$ adults, Mountain of Orsomarso, eastern side of Timpone Vaccaro, $39^{\circ} 49^{\prime} \mathrm{N} 16^{\circ} 02^{\prime} \mathrm{E}, 1255 \mathrm{~m}$, Saracena (CS), 22.08.18, 6.08.19 e 15.08.19, SP; 1 đadult, Mountains of Orsomarso, at Rifugio Mare Piccolo, 3948'N $16^{\circ} 01^{\prime} \mathrm{E}, 1185 \mathrm{~m}$, Orsomarso (CS), 6.08.19, SP; 1 $q$ adult, Mountains of Orsomarso, Serra Paratizzi, 3943'N 1559'E, 1763 m, San Donato di Ninea

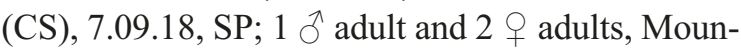


tain of Orsomarso, Frida, 39 $42^{\prime} \mathrm{N} 16^{\circ} 00^{\prime} \mathrm{E}, 1300$ $\mathrm{m}$, San Donato di Ninea (CS), 9.08.18, 14.08 .18 e 23.08.18, SP \& MT; 1 ㅇ adult, Mountain of Orsomarso, Valley of Vespa, 3944'N 1601'E, $1695 \mathrm{~m}$, San Donato di Ninea (CS), 7.09.18, SP; 1 ô adult and $1 q$ adult, Mountains of Orsomarso, Cozzo del Pellegrino, 1900 m, San Donato di Ninea (CS), 7.09.18, SP; 1 adult, Mountains of Orsomarso, at Carpinosa, 3945'N 1559'E, 800 m, San Donato di Ninea, 12.08.19, SP; 1 adult, Mountains of Orsomarso, Nona, 3945'N 1559'E, 1020 m, San Donato di Ninea (CS), 12.08.19, SP; 1 q adult, Mountains of Orsomarso, Sferracavallo, $39^{\circ} 41^{\prime} \mathrm{N}$ 15'59'E, $1285 \mathrm{~m}$, San Donato di Ninea (CS), 25.07.19, SP; 1 adult, Mountains of Orsomarso, Piano di Marco, 3941'N 1600'E, 1050 m, San Donato di Ninea (CS), 6.08.19, MT; $1 \delta$ adult and $2 q$ adults, Mountains of Orsomarso, Strette di Prezzamano, 39³9'N 1559'E, $1160 \mathrm{~m}$, Mottafollone (CS), 7.08.18, 18.07.19 e 28.07.19, SP \& MT; 1 q adult, Mountains of Orsomarso, Campicello, 1080 m, 39³9'N 1558'E, 1080 m, Mottafollone (CS), 28.07.19, SP; 1 त adult, Mountains of Orsomarso, Monte Prezzamano, 39³9’ N 1559'E, 1195 m, Mottafollone (CS), 28.07.19, SP; 1 đิ adult, Mountains of Orsomarso, Pietra Portusata, 39³9'N 1558'E, 1167 m, Mottafollone (CS), 28.07.19, SP; 1 adult, Mountains of Orsomarso, Scrigna dell'Asino, 39³9'N 1557'E, 1178 m, Sant'Agata di Esaro (CS), 28.07.19, SP; 1 adult, Mountains of Orsomarso, La Montea, 39³9’N 1557’E, 1650 m, Mottafollone (CS), 11.08.19, SP; 1 q adult, Mountains of Orsomarso, Pietra del Cisso, $39^{\circ} 40^{\prime} \mathrm{N}$ 1554'E, 1372 m, Buonvicino (CS), 7.08.19, SP \& MT; 1 q adult, Mountains of Orsomarso, northern side of Monte Frattina, 3940’N 1554'E, 1475 m, Buonvicino (CS), 7.08.19, SP \& MT; 1 ऽ adult and 1 q adult, Mountains of Orsomarso, northern side of Monte Petricelle, 39³9’ N 1554'E, $1462 \mathrm{~m}$, Buonvicino (CS), 7.08.19, SP \& MT; 1 adult,

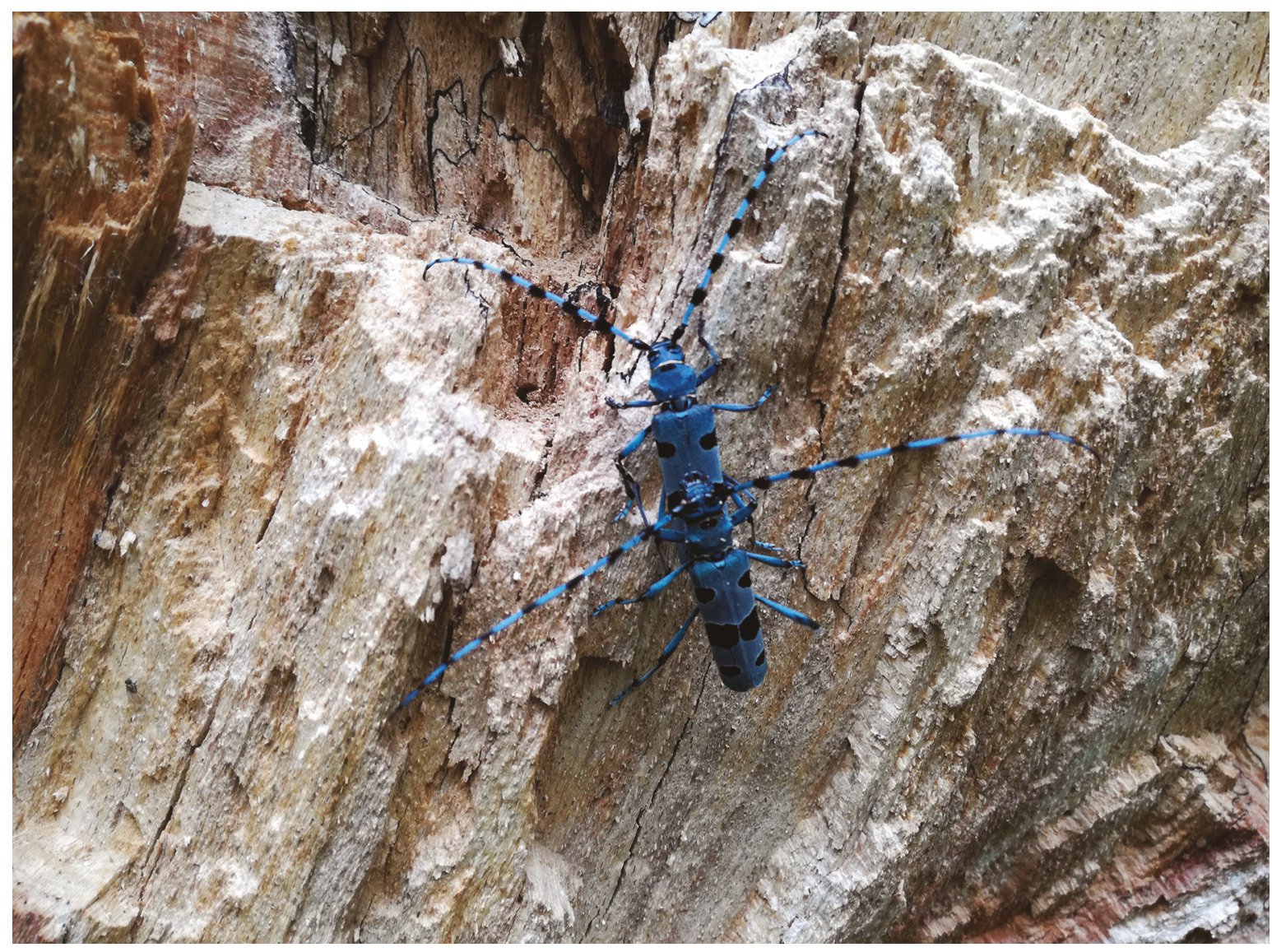

Figure 5. Rosalia alpina near Piano della Fagosa, Pollino (photo S. Piazzini). 
Mountains of Orsomarso, northern side of Monte Petricelle, $39^{\circ} 39^{\prime} \mathrm{N} 15^{\circ} 55^{\prime} \mathrm{E}, 1750 \mathrm{~m}$, Buonvicino (CS), SP \& MT.

OBSERVATIONS. Species widespread in central and southern Europe, from southern Scandinavia to the Iberian peninsula and Italy, from Russia through the Balkan peninsula to northern Turkey; in the southern portion of the range it is present with a very fragmented distribution. In Italy it is alerted in all regions with the exception of Sardinia and the Aosta Valley, but is more frequent along the Apennine arc. Rosalia alpina is mainly linked to mature beech woods, generally from high hills $(500 \mathrm{~m})$ up to mountain altitudes $(1500 \mathrm{~m})$.

It prefers old woods with a prevalence of beech, Fagus sylvatica, with the presence of perishing and dead plants, and the larva feeds on those routings; more rarely it lives also on other broad-leaf trees (in particular Acer, Quercus, Ulmus, Fraxinus, Castanea and Alnus). The period of flickering varies according to altitude and climate, but generally between May and August (Mazzei et al., 2013; Trizzino et al., 2013; Campanaro et al., 2017; Mazzei \& Brandmayr, 2017). The species is mentioned in Annexes II and IV of Directive 92/43/ EEC and is considered "Almost threatened" in Italy and "Least Concern" globally (Verdugo et al., 2016 in IUCN, 2020; Rondinini et al., 2013 in IUCN Italian Committee, 2020).

In the Calabrian side of the Pollino National Park, $R$. alpina was known with certainty in only two ZSC, IT9310014 La Fagosa-Timpa dell'Orso and IT9310021 Cozzo del Pellegrino (Mazzei et al., 2013; Mazzei \& Brandmayr, 2017). On the basis of our findings, however, it was rather widespread, even common in some more limited areas and having been found in thirty-eight locations, almost all unpublished. It is mainly located in La Fagosa and Orsomarso, especially on the Ionian side, while it is probably more isolated at Sparviere Mountain, at

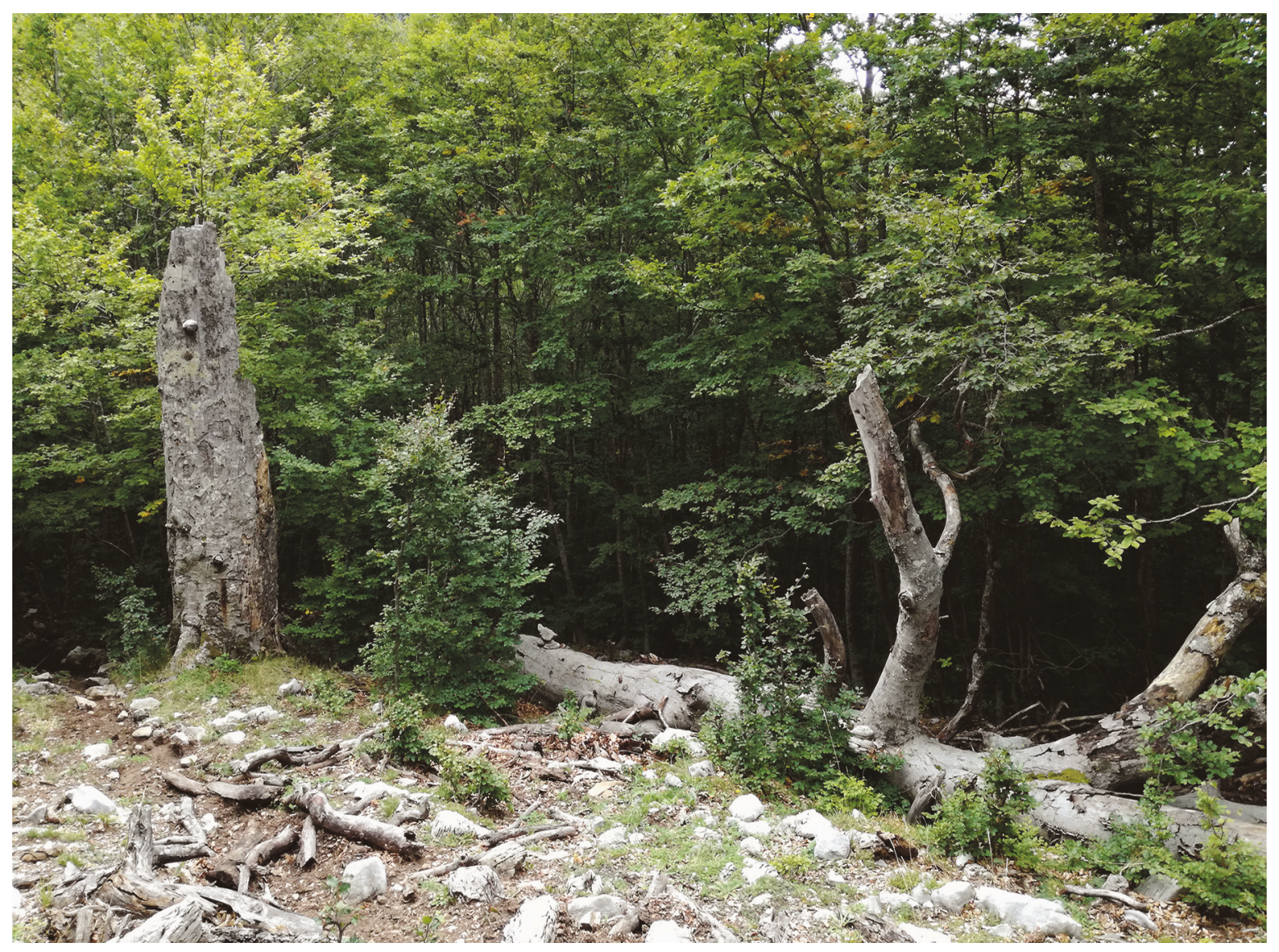

Figure 6. Habitat of Rosalia alpina near Serra del Prete, Pollino (photo S. Piazzini). 
the northeastern end of Pollino and at Gada Mountain, in Chain of Ciagola.

Despite the good diffusion, the sampling carried out in four locations (Fosso del Vascello, Piano della Fagosa, Acqua di Frida and Campicello) with CMR, however, revealed modest populations (maximum eight specimens). These results are quite similar to those obtained with the same methods in the Casentinian Forests National Park, but very different from those observed in the Abruzzo National Park, where up to 172 specimens were detected on transepts with 15 dead plants (Campanaro et al, 2017). This significant difference, however, could not depend on the actual size of the populations but on their distribution in the habitat: it is possible that $R$. alpina is widespread but with smaller metapopulations where there is a larger habitat (NP of Pollino and NP of Casentinian Forests), while it is present with more abundant point populations (NP of Abruzzo) where the habitat is more localized.

Twenty-seven locations fall into Special Conservation Zones: eleven in the ZSC IT9310014 Fagosa-Timpa dell'Orso IT9310014, five in the ZSC IT9310032 Serrapodolo, four in the ZSC IT9310028 Valle del Fiume Abatemarco, three in the ZSC IT9310022 Piano di Marco, one in the ZSC IT9310023 Valle of the Argentino River, one in the ZSC IT9310027 Rosa River and one in the ZSC IT9310029 La Montea. The detected places are located from $800 \mathrm{~m}$ up to $1900 \mathrm{~m}$, which represents the highest altitude ever recorded in Italy, and are all characterized by mature or old woods, generally with a prevalence of beech, with the presence of at least three to four dead plants of large size (standing or on the ground) or perishing distributed in a minimum area of 0.5 ha.

Rosalia alpina was detected in thirty-five cases out of thirty-eight of beech (92\%). Numerous females have been observed in egg-laying who seem to prefer the stubs of large plants, dead on their feet and broken for a relatively short time (Fig. 6). In three cases (Frida, Piano di Marco and Sparviere Mountain) it was detected on Italian alder ( $8 \%)$ and in two of these it was observed to lay eggs, a fact that represents the first case documented in Italy confirming a relative polyphagia of the species, which probably occurs in portions of old woods and in marginal areas not too far from the primary habitat represented, in fact, by beech woods. From the available data, the flickering occurs from the beginning of July, at the lowest altitudes (around 1000 $\mathrm{m})$ until the end of August at the highest altitudes (1800-1900 m). R. alpina was found in syntopia with $O$. italicum in six locations, while in two of these (Piano di Marco and Monte Gada) it also lives with L. tetraodon and M. asper.

In relation to the territory under investigation, the greatest threats seem to be represented by the illegal cutting of perishing plants, the removal of dead trunks and fires; however, illegal collection for collection purposes should not be underestimated.

\section{CONCLUSIONS}

From the above results it is clear that the Pollino National Park plays a primary importance role at national level for the protection of $L$. tetraodon, O. italicum, $C$. cerdo and $R$. alpina. It is an entity of conservation interest pursuant to Directive 92/43/ EEC as priority ( $R$. alpina), and endemic, sub-endemic or of biogeographical interest. In all cases, these are umbrella species whose protection makes it possible to conserve the other saproxylic species and with them the old forests, habitats that are gradually decreasing on a global level, vital for the survival of a large number of animal species among the invertebrates and vertebrates. This is possible, however, only through the promotion of specific studies and research that highlight the areas of greatest naturalistic value and allow the authorities in charge to take the necessary actions for rigorous protection without which the future of these habitats and species is seriously at risk.

\section{ACKNOWLEDGMENTS}

We are grateful to the Pollino National Park Authority (Santa Maria della Consolazione Rotonda, Potenza, Italy); to Nevio Agostini, Massimo Bartolini, Rossana Bruschi, Marco Di Luca, Lorenzo Foggi, Sarah Gonnelli, Mimmo Lauria, Alessandro Pace, Francesco Pinzauti, Carmen Piritore, Iuri Sbrilli, Sem Scaramucci who participated in the field research; to Greta Martiri for the English traduction of the text. 


\section{REFERENCES}

Audisio P., Brustel H., Carpaneto G.M., Coletti G., Mancini E., Piattella E., Trizzino M., Dutto M., Antonini G. \& De Biase A., 2007. Updating the taxonomy and distribution of the European Osmoderma, and strategies for their conservation (Coleoptera, Scarabaeidae, Cetoniinae). Fragmenta Entomologica, 39: 273-290. https://doi.org/10.4081/fe.2007.124

Audisio P., Brustel H., Carpaneto G.M., Coletti G., Mancini E., Trizzino M., Antonini G., De Biase A., 2009. Data on molecular taxonomy and genetic diversification of the European Hermit beetles, a species-complex of endangered insects (Coleoptera: Scarabaeidae, Cetoniinae, Osmoderma). Journal of Zoological Systematics and Evolutionary Research 47: 88-95. https://doi.org/10.111/j.1439-0469.2008. 00475.x

Audisio P., Baviera C., Carpaneto G.M., Biscaccianti A.B., Battistoni A., Teofili C. \& Rondinini C. (compilatori), 2014. Lista Rossa IUCN dei Coleotteri saproxilici Italiani. Comitato Italiano IUCN e Ministero dell'Ambiente e della Tutela del Territorio e del Mare, Roma.

Avena G.C. \& Bruno F., 1975. Lineamenti della vegetazione del massiccio del Pollino, Appennino calabrolucano. Notiziario Fitosociologico, 10: 131-153.

Bardiani M., Chiari S., Maurizi E., Tini M., Toni I., Zauli A., Campanaro A., Carpaneto G.M. \& Audisio P., 2017. Guidelines for the monitoring of Lucanus cervus. In: Carpaneto G.M., Audisio P., Bologna M.A., Roversi P.F. \& Mason F. (Eds.), Guidelines for the Monitoring of the Saproxylic Beetles protected in Europe. Nature Conservation, 20: 37-78. https:// doi.org/10.3897/natureconservation.20.12687

Beltrán F.M. \& Beltrán Á. M., 2009. Lucanus tetraodon Thunberg, 1806, Nuevo Lucánido para la península ibérica (Coleoptera, Lucanidae). Boletín Sociedad Entomológica Aragonesa, 45: 289-291.

Bologna M.A., Rovelli V. \& Zapparoli M., 2016. Invertebrati. In: Stoch F. \& Genovesi P. (Eds.), Manuali per il monitoraggio di specie e habitat di interesse comunitario (Direttiva 92/43/CEE) in Italia: specie animali. ISPRA, Serie Manuali e linee guida, 141/2016: xii $+364 \mathrm{pp}$.

Campanaro A., Redolfi De Zan L. Antonini G., Hardersen S., Chiari S., Cini A., Mancini E., Mosconi F., Rossi de Gasperis S., Solano E., Bologna M. \& Sabbatini Peverieri G., 2017. Guidelines for the monitoring of Rosalia alpina. Nature Conservation, 20: 165-203.

Carpaneto G. M., Audisio P., Bologna M.A., Roversi P.F. \& Mason F. (a cura di), 2017. Linee guida per il monitoraggio dei coleotteri saproxilici protetti in Europa. Progetto LIFE11 NAT/IT/000252 MIPP. Pensoft Publishers, Sofia, Bulgaria.
Gargano D., Mingozzi A., Massolo A., Rinaldo S. \& Bernardo L., 2012. Patterns of vegetation cover/dynamics in a protected Mediterranean mountain area: Influence of the ecological context and protection policy, Plant Biosystems - An International Journal Dealing with all Aspects of Plant Biology: Official Journal of the Societa Botanica Italiana, https://doi.org/10.1080/11263504.2011.641689.

Iannace A., Garcia-Tortosa F.J. \& Vitale S., 2005. Triassic metasedimentary successions across the boundary between the southern Apennines and the Calabrian Arc (northern Calabria, Italy). Geol. J. 40, 155e171. http://dx.doi.org/10.1002/gj.1001.

Iannace A., Vitale S., D’Errico M., Mazzoli S., Di Staso A., Macaione E., Messina A., Reddy S.M., Somma R., Zamparelli V., Zattin M. \& Bonardi G., 2007. The carbonate tectonic units of northern Calabria (Italy): a record of Apulian palaeomargin evolution and Miocene convergence, continental crust subduction, and exhumation of HP LT rocks. Journal of the Geological Society, 164, 1165e1186. http://dx.doi.org/10. 1144/0016-76492007-017.IUCN, 2019. The IUCN Red List of Threatened Species. Version 2019-1. https://www.iucnredlist.org. last accessed 24.10.2019

IUCN Comitato Italiano, 2019. https://www.iucn.it/listerosse-italiane.php last accessed 24.10.2019

Mazzei A., Bonacci T., Gangale C., Pizzolotto R. \& Brandmayr P., 2013. Nuovi dati faunistici ed ecologici de Rosalia alpina (Linnaeus, 1758) in Calabria. Quaderno di Studi e Notizie di Storia Naturale della Romagna, 38: 181-190.

Mazzei A., Bonacci T., Laudati M., Luzzi G., Dutto M. \& Brandmayr P., 2014. Osservazioni sul ritrovamento di Osmoderma italicum Sparacio, 2000 (Coleoptera Scarabaeidae Cetoniinae) nel Parco Nazionale della Sila (Calabria, Italia) e revisione della presenza storica nell'Italia Meridionale. Il Naturalista siciliano, 38: 331-337.

Mazzei A. \& Brandmayr P., 2017. Invertebrati in Direttiva Habitat 92/43/CEE presenti in Calabria. PanLife Natura 2000 Action Programme - LIFE13 NAT/IT/00 1075 Azione D1

Redolfi De Zan L., Bardiani M., Antonini G., Campanaro A., Chiari S., Mancini E., Maura M., Sabatelli S., Solano E., Zauli A., Sabbatini Peverieri G. \& Roversi P.F., 2017. Guidelines for the monitoring of Cerambyx cerdo. In: Carpaneto G.M., Audisio P., Bologna M.A., Roversi P.F. \& Mason F. (Eds.), Guidelines for the Monitoring of the Saproxylic Beetles protected in Europe. Nature Conservation, 20: 129-164. https:// doi.org/10.3897/natureconservation.20.12703

Ruffo S. \& Stoch F. (a cura di), 2007. Ckmap: Checklist and distribution of the italian fauna. Ministero dell'Ambiente Servizio di Conservazione della Natura. CD Rom 
Sforzi A. \& Bartolozzi L. (a cura di), 2001. Libro Rosso degli Insetti della Toscana. Agenzia Regionale per lo Sviluppo e 1'Innovazione nel settore Agricolo-forestale, Firenze, 375 pp.

Sindaco R., Trovò P.V. \& Gola G., 2019. Il genere $L u$ canus in Piemonte (Coleoptera: Lucanidae). Rivista piemontese di Storia naturale, 40: 305-316.

Stoch F. \& Genovesi P. (Eds.), 2016. Manuali per il monitoraggio di specie e habitat di interesse comunitario (Direttiva 92/43/CEE) in Italia: specie animali. ISPRA, Serie Manuali e linee guida, 141/2016: xii+364 pp.

Trizzino M., Audisio P., Bisi F., Bottacci A., Campanaro
A., Carpaneto G.M., Chiari S., Hardersen S., Mason F., Nardi G., Preatoni D.G., Vigna Taglianti A., Zauli A., Zilli A. \& Cerretti P. (Eds.), 2013. Gli artropodi italiani in Direttiva Habitat: biologia, ecologia, riconoscimento e monitoraggio. Quaderni Conservazione Habitat, 7. CFS-CNBFVR, Centro Nazionale Biodiversita Forestale. Cierre Grafica, Sommacampagna, Verona, $256 \mathrm{pp}$.

Zilioli M. \& Pittino R., 2004. Un reperto eccezionale: Lucanus tetraodon Thunberg in Lombardia (Coleoptera, Lucanidae). Atti della Società Italiana di Scienze Naturali e del Museo Civico di Storia Naturale in Milano, 145: 301-306. 